\title{
PROBLEMY WYCHOWAWCZE I ŚRODOWISKOWE W ZESPOLE NADPOBUDLIWOŚCI PSYCHORUCHOWEJ - STUDIUM PRZYPADKU
}

\author{
EDUCATIONAL AND ENVIRONMENTAL PROBLEMS IN ATTENTION DEFICIT HYPERACTIVITY \\ DISORDER - CASE STUDY
}

Joanna Świerczek, Marta Grabek

Katedra Pielęgniarstwa i Położnictwa

Szkoła Wyższa Planowania Strategicznego w Dąbrowie Górniczej

DOI: https://doi.org/10.20883/pielpol.2017.22

\section{STRESZCZENIE}

Założenia. Dziecko z ADHD wymaga pomocy w organizacji świata zewnętrznego, stałego systemu norm i zasad, stymulowania rozwoju zdolności do samokontroli i usprawniania procesów poznawczych. Konieczne jest też podjęcie nad jego samooceną pracy stanowi ona podstawowy element profilaktyki wtórnych objawów zespołu nadpobudliwości psychoruchowej $z$ deficytem uwagi. Celem własnych analiz była próba określenia wpływu oddziaływania terapeutycznego oraz oddziaływania opiekuńczo-wychowawczego na rozwój dziecka objętego badaniem.

Prezentacja przypadku. W analizach własnych badaniem objęto 12-letniego chłopca o prawidłowym rozwoju fizycznym i motorycznym oraz wysokiej sprawności fizycznej. Na podstawie zebranych wyników dotychczas przeprowadzonych badań medycznych oraz na podstawie opinii Poradni Psychologiczno-Pedagogicznej stwierdzono występowanie u dziecka zespołu nadpobudliwości psychoruchowej z zaburzeniami koncentracji uwagi oraz szeregiem trudności w funkcjonowaniu chłopca w środowisku rodzinnym, szkolnym oraz w społeczeństwie. Celami oddziaływań terapeutycznych były: ujednolicenie oraz harmonizacja rozwoju procesów poznawczych, doskonalenie koncentracji uwagi, analizy i syntezy wzrokowej, koordynacji wzrokowo-ruchowej, które miały przyczynić się do pokonania trudności w nauce. Natomiast celami oddziaływań opiekuńczo-wychowawczych były: praca nad prawidłowym funkcjonowaniem chłopca w grupie rówieśniczej, poprawa jakości i organizacji działań podejmowanych przez dziecko, uczenie go panowania nad emocjami, wyrobienie umiejętności pokonywania trudności i radzenia sobie z niepowodzeniami szkolnymi. Działania te miały pozytywnie wpłynąć na samoocenę i sposób, w jaki dziecko jest postrzegane przez otoczenie.

Wyniki. Zadania opiekuńczo-wychowawcze wobec chłopca objętego analizą realizowane były przez nauczycieli, rodziców oraz psychoterapeutę w placówce szkolnej w trakcie codziennych zajęć dydaktycznych oraz zajęć pozalekcyjnych, jak również w domu dziecka. Realizacja wszystkich zadań była zgodna z zaleceniami zawartymi w opinii wydanej przez Poradnię Psychologiczno-Pedagogiczną. Przeprowadzano systematyczne rozmowy z rodzicami chłopca, konsultacje z pedagogiem szkolnym. Istotne znaczenie miała współpraca z psychoterapeutą. Zajęcia wyrównujące wiedzę $\mathrm{i}$ indywidualne rozmowy, w trakcie których chłopiec nawiązał bliższy kontakt z wychowawcą, ułatwiły mu pokonywanie trudności i dyskretne rozwiązywanie bieżących problemów wychowawczych. Podejmowane działania miały wielokierunkowy charakter i pozwoliły nie tylko na ujednolicenie i harmonizację rozwoju chłopca, ale również na poprawę jego sytuacji w szkole.

SŁOWA KLUCZOWE: ADHD, psychoterapia, psychoedukacja.

\section{ABSTRACT}

Assumptions. A child with ADHD needs help in the organization of the external world, a permanent system of norms and rules, stimulate the development of self-control and ability to improve cognitive processes. It is also necessary to work on his/her selfesteem, the production of which is an essential element of prophylactic secondary symptoms of attention deficit hyperactivity disorder with attention deficit.

Case report. The research included a twelve year old boy with normal physical and motor development and high physical activity. On the basis of the collected material the child was diagnosed with attention deficit hyperactivity disorder attention and many difficulties concerning his functioning in the family, school and society. The aim of therapeutic activities was standardization and harmonization of cognitive processes development, concentration improvement, visual analysis and synthesis, visual motor coordination, which are expected to contribute to overcoming learning difficulties. By contrast, the aim of care and education actions was to work on the boy's proper functioning in a peer group, improve of the quality and organization of work, learn to self-control emotions, work out skills and overcome difficulties, cope with school failure, positively affect the self-esteem and its reception in the environment.

Results. Care and education tasks implemented during daily classes and extracurricular activities, were based on the psychological and educational opinion, regular conversations with his parents, consultations with the school counselor, and cooperation with the therapist. Classes leveling knowledge and individual interviews, during which the boy was in a close relationship with the teacher, facilitated overcoming difficulties and discreet solving current educational problems. The actions taken were of multidirectional nature and allowed not only to unify and harmonize the development of the boy, but also to improve his situation at school. 


\section{Wprowadzenie}

Zespół nadpobudliwości psychoruchowej z deficytem uwagi (ang. attention deficyt hyperactivity disorder ADHD) przez specjalistów zaliczany jest do zaburzeń hiperkinetycznych charakterystycznych dla okresu dzieciństwa, prowadzących do istotnego upośledzenia funkcjonowania bio-psycho-społecznego dziecka oraz zwiększających ryzyko wystąpienia innych zaburzeń psychicznych, takich jak: zaburzenia zachowania czy nadużywanie substancji psychoaktywnych. Współcześnie w piśmiennictwie specjalistycznym stosowane są równolegle dwie, równoprawne nazwy tego schorzenia: amerykańska, czyli zespół ADHD, traktująca schorzenie jako nadpobudliwość psychoruchową z zaburzeniami koncentracji uwagi, oraz europejska: hyperkinetic disorder, traktująca schorzenie jako zespół hiperkinetyczny lub zaburzenia hiperkinetyczne [1]. Według Hallowella zespół nadpobudliwości psychoruchowej z deficytem uwagi jest zaburzeniem neurologicznym, na które składa się klasyczna triada następujących objawów: impulsywność, zaburzenia koncentracji i nadruchliwość lub nadmiar energii [2].

Zespół ADHD występuje na całym świecie i jest rozpoznawany niemal we wszystkich kulturach. Metaanalizy dostępnych badań prowadzonych w tym zakresie dowodzą, że rozpowszechnienie tej jednostki chorobowej na całym świecie wynosi około 3,5\% dla populacji dzieci i młodzieży oraz 4,4\% dla osób dorosłych [2]. Szczyt rozpowszechnienia ADHD przypada pomiędzy 6. a 9. rokiem życia dziecka i jest bezpośrednim następstwem niemożności adaptacji nieuważnego, nadmiernie ruchliwego oraz impulsywnego dziecka do sytemu szkolnego. Objawy zespołu nadpobudliwości psychoruchowej z deficytem uwagi w części przypadków są obecne również w okresie dorastania oraz w dorosłym życiu. Jak wskazują specjaliści, objawy charakterystyczne dla ADHD mogą utrzymywać się w około $70 \%$ u osób w okresie dorastania oraz u 30-50\% osób dorosłych. Analiza dostępnego materiału pozwala na stwierdzenie, że częściej zespołem hiperkinetycznym dotknięci są chłopcy. W zależności od użytych przez badaczy kryteriów diagnostycznych proporcje między częstością występowania ADHD u dziewcząt i chłopców przedstawiają się różnorodnie - od 1:10, poprzez 1:20 w grupach klinicznych, aż do 1:4, a nawet 1:2,5 w określonych grupach populacyjnych [3].

\section{Cel pracy}

Celem własnych analiz była próba określenia wpływu oddziaływania terapeutycznego oraz oddziaływania opiekuńczo-wychowawczego na rozwój dziecka objętego badaniem.

\section{Opis przypadku}

Do przeprowadzenia badań wykorzystano metodę obserwacyjną bez interwencji badacza. Do opisu tego przypadku posłużono się danymi z dokumentów (orzeczenia Poradni Psychologiczno-Pedagogicznej, książeczka zdrowia dziecka, opinie nauczycieli szkolnych i przedszkolnych), arkuszy obserwacji, kwestionariuszy wywiadu. Dokonując tego wyboru, kierowano się następującymi kryteriami: wiek, stopień nasilenia objawów chorobowych, możliwość częstego przebywania obserwatora w otoczeniu dziecka, różnorodność zachowań chłopca, łatwość nawiązywania kontaktu przez dziecko oraz możliwość przeprowadzenia wiarygodnego i wyczerpującego wywiadu.

Analizą objęto 12-letniego chłopca z prawidłowym rozwojem fizycznym, prawidłowym rozwojem motorycznym oraz wysokim poziomem sprawności fizycznej. W wywiadzie rodzinnym dziecka stwierdzono wpływ zdiagnozowanego nowotworu gruczołu piersiowego u matki oraz wynikających z niego wielokrotnych hospitalizacji na zaostrzenie objawów zespołu nadpobudliwości psychoruchowej z deficytem uwagi u dziecka, wystąpienie lęku, niepokoju oraz obniżonej samooceny.

\section{Rozpoznane problemy}

Badania psychologiczne przeprowadzone u dziecka potwierdziły jego ponadprzeciętny, choć nieharmonijny rozwój umysłowy, pozwalający na realizację programu szkoły masowej. Niemniej jednak chłopiec wykazywał wyraźne trudności w sprostaniu sytuacji zadaniowej, nieumiejętność skupienia uwagi, obniżoną funkcję percepcyjno-motoryczną, opóźnienie w sferze emocjonalno-motywacyjnej, wyraźne cechy obniżonego krytycyzmu oraz szereg cech charakterystycznych dla zespołu nadpobudliwości psychoruchowej. Zachowania te wpłynęły w sposób negatywny na postępy edukacyjne i wychowawcze chłopca. Niepowodzenia szkolne z zakresu edukacji polonistycznej i matematycznej zniechęcały go do dalszej pracy. Dodatkowo problemy z zachowaniem dziecka wzbudzały niechęć jego rówieśników do kontaktów z nim, a chłopiec zaczął wykazywać wysoki stopień agresji wobec najbliższego otoczenia.

Na podstawie wyników badań lekarskich oraz opinii Poradni Psychologiczno-Pedagogicznej stwierdzono występowanie u dziecka zespołu nadpobudliwości psychoruchowej z zaburzeniami koncentracji uwagi oraz szeregiem trudności w funkcjonowaniu chłopca zarówno w środowisku rodzinnym, jak i w środowisku szkolnym oraz w społeczeństwie. 


\section{Działania podjęte w celu rozwiązania problemów występujących u dziecka}

Celami oddziaływań terapeutycznych podjętych wobec dziecka były: ujednolicenie oraz harmonizacja rozwoju procesów poznawczych, doskonalenie koncentracji uwagi, analizy i syntezy wzrokowej oraz koordynacji wzrokowo-ruchowej, które w konsekwencji miały przyczynić się do pokonania trudności w nauce. Działania te realizowane były przez pracowników Poradni Psychologiczno-Pedagogicznej, pod której opieką znajduje się chłopiec, oraz przez psychoterapeutę pracującego na zlecenie rodziców, i miały na celu: rozwijanie sprawności manualnej oraz usprawnienie grafomotoryki ręki wiodącej, rozwijanie percepcji wzrokowej, słuchowej, koordynacji wzrokowo-słuchowej, rozwijanie słuchu fonematycznego, doprowadzenie do samodzielnego wykonania zadania zgodnie z poleceniem nauczyciela, wyrobienie czujności ortograficznej dotyczącej pisowni wyrazów ze zmiękczeniami, dwuznakami, ze zwróceniem uwagi na popełniane na bieżąco błędy ortograficzne, przestrzeganie dotychczas poznanych regut ortograficznych, stosowanie ćwiczeń w czytaniu ze zrozumieniem z nastawieniem dziecka na zapamiętywanie informacji; rozwijanie i koordynowanie rozwoju procesów, które są zaangażowane w uczenie się matematyki (rozwijanie procesów poznawczych, usprawnianie percepcji wzrokowej i słuchowej oraz koordynacji wzrokowo-ruchowej, trening w zakresie uważnego słuchania instrukcji i wychwytywania informacji istotnych dla zrozumienia i respektowania reguł, trening skupiania uwagi, trening rozumowania w grach, zabawach i zadaniach). Aby osiągnąć te cele, dostosowano warunki w sali lekcyjnej do potrzeb chłopca i przydzielono mu miejsca w pierwszej ławce, w sali lekcyjnej umieszczono plansze informujące o regułach, zasadach postępowania oraz postępach w ich przestrzeganiu, dbano o atrakcyjność i różnorodność zajęć, przygotowanie jasnej, przejrzystej struktury lekcji, staranne planowanie czasu, uwzględnianie potrzeby zmiany rodzaju aktywności uczniów podczas zajęć, wprowadzanie różnych aktywizujących metod i form pracy, włączanie krótkich ćwiczeń ruchowych w przerwy między lekcjami. Nauczyciele powtarzali również najważniejsze elementy lekcji, zapisywali je we właściwej kolejności na tablicy, zachęcali chłopca oraz pozostałych uczniów do zadawania pytań. Angażowali także pozostałych uczniów we wzajemną pomoc w nauce, przydzielali role $z$ uwzględnieniem mocnych stron każdego ucznia, chwalili postępy w działaniach podejmowanych przez chłopca z własnej inicjatywy oraz wzmacniali poczucie własnej wartości chłopca przez udział w sukcesach kolegów.
Celami oddziaływań opiekuńczo-wychowawczych realizowanych przez nauczycieli oraz rodziców dziecka były: praca nad prawidłowym funkcjonowaniem chłopca w grupie rówieśniczej, poprawa jakości i organizacji jego pracy, uczenie panowania chłopca nad emocjami, wyrobienie w nim umiejętności pokonywania trudności oraz radzenia sobie z niepowodzeniami szkolnymi. Działania te miały pozytywnie wpłynąć na samoocenę chłopca oraz jego odbiór w otoczeniu. Działania wychowawcze realizowane przez nauczycieli i rodziców odnosiły się przede wszystkim do pokazania dziecku, czego się od niego oczekuje, stanowczego reagowania na niepożądane zachowanie chłopca, pokazania mu, w jaki sposób naprawić złe uczynki, pozwolenia na ponoszenie konsekwencji złego zachowania, ustalenia stałych i niezmiennych elementów dnia.

Zadania wychowawcze wobec chłopca objętego obserwacją realizowano w placówce szkolnej w trakcie codziennych zajęć dydaktycznych oraz w placówce szkolnej i w Poradni Psychologiczno-Pedagogicznej w ramach zajęć pozalekcyjnych, na podstawie opinii wydanej przez Poradnię Psychologiczno-Pedagogiczną, systematycznych rozmów z rodzicami chłopca, konsultacji z pedagogiem szkolnym. Zadania opiekuńczo-wychowawcze wobec dziecka realizowane były również w domu przez rodziców. Zajęcia wyrównujące wiedzę i indywidualne rozmowy, w trakcie których chłopiec nawiązał bliższy kontakt z wychowawcą, ułatwiły w znaczący sposób pokonywanie trudności i dyskretne rozwiązywanie bieżących problemów wychowawczych. Pozwoliły one również na podniesienie samooceny dziecka oraz poprawę jego relacji z rówieśnikami. Wszystkie działania opisane w niniejszym tekście realizowane były przez jeden semestr zajęć szkolnych.

\section{Dyskusja}

Trudności w uczeniu się w przypadku dzieci z nadpobudliwością psychoruchową powiązane są z zaburzeniami procesów uwagi i pamięci [4]. Do najpoważniejszych konsekwencji zaburzeń uwagi zalicza się niewykorzystanie przez dziecko jego moźliwości oraz zbyt wczesne zakończenie kariery szkolnej. Brak koncentracji niejednokrotnie bywa interpretowany jako lenistwo, brak odpowiedzialności, brak zainteresowania czy wreszcie zachowanie opozycyjne [5]. Problemy z impulsywnością i kontrolą zachowań powodują, że dziecko z ADHD nie potrafi przewidywać konsekwencji swojego działania i choć zna reguły postępowania w szkole, ma problem z ich właściwym stosowaniem. Często jest odrzucane przez grupę rówieśniczą, nieakceptowane w klasie i krytykowane przez dorosłych [6-8]. Rodzice dziecka z ADHD mają także bardzo częstą styczność 
z kłamstwem dziecka, będącym jego sposobem radzenia sobie w trudnych sytuacjach [9].

Postępowanie z dzieckiem nadpobudliwym psychoruchowo musi być zawsze wielokierunkowe (multimodalne) i oddziaływać zarówno na samo dziecko, jak i na jego otoczenie. Niezbędne jest więc połączenie poradnictwa, oddziaływania psychospołecznego, a $\mathrm{w}$ razie potrzeby psychoterapii i farmakoterapii. W związku z podkreślanym w piśmiennictwie specjalistycznym znaczeniem wielokierunkowości działań również w przypadku dziecka objętego obserwacją wdrożono te założenia, proponując rodzicom zarówno wsparcie w oddziaływaniach opiekuńczo-wychowawczych, jak również szereg działań terapeutycznych i wyrównawczych.

Leczenie zespołu hiperkinetycznego jest wieloletnie i czynnie angażuje nie tylko lekarza prowadzącego dany przypadek, ale również rodzinę i szkołę dziecka. Często wskazane są: terapia indywidualna lub grupowa, trening umiejętności społecznych, terapia zaburzeń uwagi i odpowiednia postawa osób bliskich [7, 8, 10]. Podstawą pracy z dzieckiem z ADHD jest rzetelna wiedza na temat nadpobudliwości psychoruchowej oraz cierpliwa, spokojna, pełna zrozumienia i życzliwości postawa personelu medycznego, rodziców i nauczycieli.

Specjaliści podkreślają, że dzieci, u których zastosowano więcej rodzajów interwencji, lepiej funkcjonują po 1-3 latach leczenia niż dzieci, u których ograniczono się tylko do jednego rodzaju działań, a w niektórych przypadkach niezbędne jest także wdrożenie bezpiecznej farmakoterapii. Działanie to podejmowane jest szczególnie u dzieci, u których sama modyfikacja metod wychowawczych oraz inne metody terapii nie dają wystarczającego efektu lub nie mogą być zastosowane [10-12].

W okresie dorastania u wielu dzieci z ADHD można zaobserwować stopniową poprawę aktywności i uwagi, szczególnie jeśli są one objęte wielowymiarową terapią. Dojrzewanie to okres, w którym młodzież przeżywa niezdefiniowany bunt przeciwko obowiązującym normom, okres, w którym pojawiają się nowe autorytety, tajemnice i pierwsze sympatie. Jest to dość trudny czas dla każdego nastolatka, zmienia się zarówno jego strona fizyczna, jak i strona umysłowa. Część nadpobudliwych nastolatków rezygnuje z wielu zadań realizowanych przez rówieśników, zniechęca się do nich, przewidując, że zrobią to źle, lub nie są w stanie wykonać tego do końca. Wśród nadpobudliwej młodzieży są również takie osoby, które widząc swoją odmienność, będą starały się w pewien sposób zapanować nad tym procesem [13]. Wiele trudnych zachowań związanych ze specyfiką funkcjonowania dziecka z zespołem nadpobudliwości psychoruchowej z deficytem uwagi wpływa na charakter komunikacji i kontakty z otoczeniem [14].

\section{Podsumowanie}

Dziecko z ADHD wymaga pomocy w organizacji świata zewnętrznego, stałego systemu norm i zasad, stymulowania rozwoju zdolności do samokontroli i usprawniania procesów poznawczych. Konieczne jest też podjęcie nad jego samooceną pracy - stanowi ona podstawowy element profilaktyki wtórnych objawów zespołu nadpobudliwości psychoruchowej z deficytem uwagi. Równolegle należy zwracać uwagę na potrzeby i problemy rodzeństwa. W świetle prezentowanych badań szczególnie istotne dla rodzeństwa dzieci z ADHD jest zaspokojenie naturalnej potrzeby uwagi rodzicielskiej oraz budowanie poczucia bezpieczeństwa i stabilności. Zaspokojenie tych potrzeb daje podstawę do prawidłowego kształtowania się postaw dziecka z ADHD wobec życia, stosunku do siebie samego i wyznaczania realnych celów $[15,16]$.

\section{Piśmiennictwo}

1. Dąbrowska M, Borkowska A. Badania aktywacji półkulowej mózgu u dzieci z zespołem deficytu uwagi z nadruchliwością. Neuropsychologiczna ocena dysfunkcji czołowej u dzieci i młodzieży z ADHD. W: Namysłowska I (red.). Zaburzenia psychiczne dzieci i młodzieży. Kraków: Biblioteka Psychiatrii Polskiej; 2000. 35-45.

2. Patycka B. Zespół nadpobudliwości psychoruchowej z zaburzeniami koncentracji uwagi. Życie Szkoły. 2002; 7: 20-128.

3. Latecka W. Zespół nadpobudliwości psychoruchowej. W: Kott T (red.). Uczeń z przewlekłą chorobą i uczeń z zaburzeniami psychicznymi w szkole ogólnodostępnej. Warszawa: MENiSW; 2005. 81-90.

4. Herda-Płonka K. Środowisko rodzinne i szkolne wobec zespołu ADHD u dzieci w młodszym wieku szkolnym. Kraków: Impuls; 2012. 45-76.

5. Namysłowska I (red.). Psychiatria dzieci i młodzieży. Warszawa: PZWL; 2007. 205-228.

6. Srebnicki T, Wolańczyk T. One są wśród nas. Dziecko nadpobudliwe w szkole i przedszkolu. Poradnik dla nauczycieli i pedagogów. Warszawa: Ośrodek Rozwoju Edukacji; 2010. 12-34.

7. Hallowel E, Ratey J. W świecie ADHD. Nadpobudliwość psychoruchowa z zaburzeniami uwagi u dzieci i dorosłych. Poznań: Media Rodzina; 2004. 56-78.

8. Prekop I, Schweizer Ch. Niespokojne dzieci: poradnik dla zaniepokojonych rodziców. Poznań: Media Rodzina of Poznań; 1997. 7-12.

9. Żebrowska M (red.). Psychologia rozwojowa dzieci i młodzieży. Warszawa: PWN; 2000. 6-9.

10. Schafer U. Dlaczego dzieci się wiercą. Warszawa: Erda; 2001. 12-17.

11. Carter Ch. ADHD/ADD. Jak pomóc dziecku ogarnąć chaos. Warszawa: PZWL; 2012. 32-35.

12. Kaja B. Zarys terapii dziecka. Bydgoszcz: Wyd. Wyższej Szkoły Pedagogicznej; 1998. 48-54.

13. Mihilewicz S. Dziecko z trudnościami w rozwoju. Kraków: Impuls; 2001. 112-115.

14. Kisch A, Pauli S. Co się dzieje z moim dzieckiem? Zaburzenia rozwoju ruchowego i postrzegania. Warszawa: PZWL; 2004. 89-92.

15. Kołakowski A. Kłopoty z planowaniem. Głos Nauczyciela. $2004 ; 16$. 
16. Komender J. Zespół nadpobudliwości psychoruchowej z deficytem uwagi. Warszawa: PZWL; 1997. 134-142.

Artykuł przyjęty do redakcji: 15.09 .2016

Artykuł przyjęty do publikacji: 01.09.2016

Źródło finansowania: Praca nie jest finansowana z żadnego źródła. Konflikt interesów: Autorzy deklarują brak konfliktu interesów.
Adres do korespondencji:

Sandra Kryska

ul. Kościelna 6

41-303 Dąbrowa Górnicza

tel. kom.: 608488185

e-mail: sandrakryska@vp.pl

Katedra Pielęgniarstwa i Położnictwa

Szkoła Wyższa Planowania Strategicznego w Dąbrowie Górniczej 